\title{
RISK MANAGEMENT CHALLENGES IN THE COVID-19 PANDEMIC
}

\author{
Vlado Radić ${ }^{1}$ \\ Nikola Radić ${ }^{2}$
}

DOI: https://doi.org/10.31410/LIMEN.2020.57

\begin{abstract}
Even before the current pandemic, humanity was faced with numerous situations that had serious global consequences. In addition to wars, nuclear radiation, cataclysmic earthquakes, volcanic eruptions, tsunamis, epidemics of SARS, swine flu, MERS, HIV, Ebola, Zika virus, they led to the cognition that humanity is powerless in the face of such disasters. Regardless of the achievements and development of science and technology, extensive and longlasting medical research, "invisible" enemies have taken millions of human lives. People have always been faced with a risk, which comes from nature, human activities, or the mistakes of the man himself. Risk is a multidimensional, multifaceted and complex phenomenon, present on a daily basis in human life. Risk management in a state of the pandemic is primarily aimed at preserving the health and lives of the entire population, and measures applied to prevent a pandemic from taking countless human lives have no alternative.
\end{abstract}

Keywords: Automotive industry, Aviation, Supply chain, Tourism, E-business.

\section{INTRODUCTION}

I nfectious diseases and associated mortality remain serious threats around the world. Some infectious diseases, such as tuberculosis and malaria, are endemic in many areas and require constant care. Others, such as influenza, fluctuate in prevalence and intensity, leaving equal problems in the economies of developed and developing countries when they occur (sudden increase in prevalence in a relatively limited area or population), develop into an epidemic (sudden increase covering a larger area or population), or when they turn into a pandemic (an epidemic that covers several countries or continents).

The risk of an epidemic (pandemic) is complex, but policy makers have the tools at their disposal to implement in response. Some reduce the likelihood of an outbreak or limit its spread. Others minimize the health impact of an outbreak, which cannot be prevented or stopped immediately. Others, again, aim to reduce the harmful economic effects (Radić et al., 2020).

Measures taken by states and their health systems to prevent and minimize the effects of coronaviruses were to reduce the frequency of coronavirus transmission and population mortality. However, restrictive measures have been accompanied by controversy due to their effectiveness in curbing the infection and potential negative economic effects. Evidence of the effects of these measures is crucial in the "reopening" phase when governments are considering abolishing them and bringing the economy back to normal. In fact, adjusting mitigation procedures and policies can greatly reduce the economic and human losses of a pandemic (Acemoglu et al., 2020, Alvarez et al., 2020, Jones et al., 2020).

$1 \quad$ Faculty of Business Economics and Entrepreneurship, Belgrade, Mitropolita Petra 8, Serbia

2 Faculty of Business Economics and Entrepreneurship, Belgrade, Mitropolita Petra 8, Serbia 
The basic measures in the fight against the virus are already standardized, mainly according to the Chinese experience and model. The same goes for various statistics and scientific methods according to one's own or global experience. Everyone agrees that "nothing will be the same anymore" and there are certain arguments for such an assessment. The damage will vary in content and scope, from moral and ethical to organizational, economic, political and geostrategic. Since this time the most developed are much more affected by the virus and suffer more damage, even those who were minimally affected or not affected at all, will suffer economic, political and other damage due to the spillover of consequences in the conditions of globalization and general interdependence that dominate international relations.

The paper analyzes the sectors most affected by the pandemic, with special reference to disrupted supply chains and evident risks.

\section{IMPLICATIONS OF COVID-19 PANDEMIC BY SECTORS}

At the beginning of the pandemic, the automotive industry suffered the biggest blow, and with the mass introduction of lockdown, the sectors of aviation (carriers and aircraft manufacturers) and tourism experienced unprecedented losses. As well as the economic crisis of 2008-2009, the new crisis caused by the coronavirus pandemic showed the weaknesses of the planning process, analysis of business risks and threats, and predictions of future events. It would be said that the consequences of the economic crisis have been forgotten and that the world was not ready for another shock, this time to health.

Even then, car manufacturers stopped working, reduced the volume of production, laid-off workers and had a multi-year decline in the number of cars produced. The crisis did not last only one year, so in some countries, the recovery was visible only after four or five years. Due to the effect of globalization, each industry is supplied with raw materials and parts from different countries in order to keep production costs low. In this regard, manufacturers from many industries are oriented towards suppliers from China. This is especially true of the fact that the automotive industry in the rest of the world imports parts worth more than 34 billion dollars from China. It is an indisputable fact that China is a very important factor in the global economy. Its importance is not only related to the status of producers and exporters of consumer products; China has become the main supplier of inputs for companies abroad. To date, about $20 \%$ of global trade in products has been in China (Radić et al., 2020).

The speed of the spread of the COVID-19 pandemic in China caused a disruption of supply chains. Restrictive measures and close the city of Wuhan, which has the largest capacity to produce car parts and equipment, as well as the restriction and complete cessation of flights from China to Europe in the first wave of the pandemic (February-April 2020), led to delays in the production of the main players in Germany, France and Italy (Volkswagen, Mercedes, Audi, Peugeot, Citroen, Fiat). In the first quarter of 2020, production was lower by $23 \%$ than in the same quarter of 2019, in the second quarter it was lower by $32.4 \%$, and in the third quarter by $22.9 \%$ (OICA, 2020). This speaks not only of a smaller number of cars produced but also of a smaller number of cars sold. Of course, during a pandemic, interest in buying new cars is much less than under normal circumstances.

The coronavirus pandemic is slowing the economy, causing panic. On the other hand, the slowdown in the economy always has a negative impact on the car industry, because people in such a situation do not think about buying a car. Problems with stopping production and laying off workers, application of so-called measures social distancing, complete recovery and getting 
back on "normal track" takes time. In short, the ability to absorb shock and get out of it better than the competition will be the key to survival and long-term prosperity. It remains for manufacturers to redefine existing strategies with suppliers in different geographical locations in the coming period, and it is likely that they will rely more on domestic suppliers in the future. Japan, for example, has already set aside 2.2 billion dollars to help companies that want to move their production base from China to Japan, and 214 million dollars to other countries (Radić et al., 2020).

The coronavirus pandemic represents a level of disorder that the automotive industry has simply not faced before. Never before have there been such broad limitations on people's ability to work, coexist, and buy things (like vehicles). All these limitations directly affect the ability to produce vehicles and sell them to consumers. The overall health of the automotive industry in 2021 depends almost entirely on the nature of the recovery that can be achieved worldwide. So far, the "soft" restrictions of some governments, especially in the US and Europe, have led to infection rates remaining high in those countries, leading to prolonged periods of reduced economic activity, as lockdown are applied and repealed differently in response to infection rates.

The pandemic has negatively affected all industries, and among the most affected are certainly airlines and air transport. With over 1.400 airlines that have 31.717 aircraft and serve 3.900 airports thanks to the support of 173 air traffic control service providers, the civil aviation sector has established an impressive global network at the service of passengers and businesses from all over the world. Airplanes are the safest and fastest means of transportation to cross oceans and borders to connect people and foster sustainable economic growth (ICAO, 2020). Almost overnight, airlines faced declining interest in travel, a flight ban and the landing of aircraft fleets. Due to several months of the suspension or low volume of flights, losses in air traffic, together with aircraft manufacturers, airports, air traffic control, travel agencies and hoteliers, are estimated at hundreds of billions of dollars. In that regard, the largest number of airlines laid off thousands of employees. A large number of smaller airlines are on the verge of bankruptcy, and the forecasts for further business are very devastating. Some analysts predict that during 2021, the decline in income and return to the level of 2019 will be more difficult and accompanied by great challenges. Based on the movement of the pandemic, the partial lifting of some restrictions, the limited number of flights during the summer season, it is estimated that the loss of airlines will be around 314 billion dollars in 2020, which is a drop of 55\% compared to the 2019 level (IATA, 2020). According to other estimates, airlines will need several years to fully recover.

Tourism is one of the fastest-growing economic sectors and is an important driver of economic growth and development. In 2018, there were 1.4 billion international tourists, which is six percent more than in 2017 (WTO, 2020). Revenues from tourism amounted to 1480 billion dollars, and passenger transport brought another 250 billion dollars. Tourism is a major source of employment globally and is a very labor-intensive sector. A high share of jobs is performed by women (54\%) and young employees, which means that the industry is considered inclusive. Also, there is indirect employment in the field of construction and infrastructure development, plus the supply of tourists with food, drinks and souvenirs. Also, many employees have direct contact with tourists in travel agencies, airlines, on ships, in hotels, restaurants, shopping malls and various tourist attractions. According to business indicators, it is obvious that the pandemic will have a longer-lasting effect on the tourism sector, while other economic sectors could recover faster. This is especially important for countries where the national economy relies heavily on the tourism industry (Croatia, Greece, Spain, Italy, Turkey, Malta, Cyprus). 
In addition to airlines, the reduction in travel has also affected hotels. According to the analytical company STR, the prices of hotel accommodation fell in all regions in March (STR, 2020). In relation to performance indicators (revenue per free room and average daily occupancy), the impact of the pandemic and travel restrictions on revenues in the same period in 2019 is obvious. Several large hotel chains, including Marriot International and Hilton Worldwide, have seen mass layoffs and pay cuts. The executive director of the Marriot International hotel chain (about 174.000 employees), said that the corona virus pandemic affected their business worse than the Great Recession and the terrorist attack on the World Trade Center in New York together. In those two major crises, the biggest quarterly drop in revenue was $25 \%$. With the onset of the coronavirus pandemic, the decline is $75 \%$, and it is believed that it will be up to $90 \%$ in the United States (Bomey, 2020). With the spread of the pandemic, Marriott sent two-thirds of its employees on forced leave. They will not be paid, but they will have health benefits as before. Hilton Worldwide has also informed lenders that it will borrow 1.75 billion dollars as a precaution to maintain flexibility "in light of the uncertainty in global markets" (Borko, 2020). Other companies in the industry, such as the online platform Expedia Group, announced in late February that they were cutting 3.000 jobs. Meanwhile, the travel site Booking Holdings - which has 27.000 employees - has suspended employment.

The tourism industry accounts for about $10.3 \%$ of global GDP and generates roughly one in four new jobs in the world in the last five years (WTTC, 2020). But the abrupt halt to global travel due to the pandemic resulted in the dismissal of more than 100 million workers worldwide during 2020. UN Secretary-General Antonio Guterres released a new report in August that relies on WTO data to quantify the devastating impact the coronavirus pandemic has had on global tourism. He warned that about 120 million jobs in tourism are endangered, with the economic damage likely to exceed 1 trillion dollars in 2020 alone. "It is necessary to renew the tourism sector in order to regain its position as a provider of decent business, stable income and protection of our cultural and natural heritage." He further emphasized the role of tourism as one of the most important economic sectors, providing livelihoods for hundreds of millions of people, while "stimulating economies and enabling countries to prosper" (Richter, 2020). Depending on when travel restrictions are completely lifted, the World Tourism Organization expects tourism revenues to fall between 910 billion dollars and 1.2 trillion dollars in 2020, which would take the global tourism industry back 20 years.

\section{RISK ASSESSMENT IN A PANDEMIC}

Even a superficial analysis of the events related to the coronavirus pandemic so far indicates the unwillingness of almost all countries in the world, their governments and health systems to successfully resist the waves of the pandemic, which has lasted for almost a year. This unequivocally points to the need to analyze the risks associated with the pandemic, especially for the lives and health of the population around the world. Political, economic, social and other risks can be discussed from the perspective of individual solutions, decisions, or public policies.

People have always been faced with a risk, which can come from nature, human activity, or the mistakes of the man himself. Risk is a multidimensional, multifaceted and complex concept, present in human life on a daily basis. As such, it has always attracted the attention of a large number of researchers and scientists, who have observed it from various aspects. For these reasons, there is no single definition of risk. However, all risks have in common that there must be future and uncertain events. Broadly speaking, the risk represents a possible negative deviation from the expected outcome. Risk is a danger that threatens a person or property (fire, 
earthquake, explosion, pandemic), i.e. risk is only the possibility that some economically harmful event will occur (Radić, 2014).

Theoretically and practically, all organizations are located and operate in conditions of uncertainty. According to the definitions, in that case it is said that the activities of each organization take place in a more or less hazardous environment. In the context of risk management terminology, the hazard is considered to be the state and environment in which there is uncertainty about the realization of desired events. Just as there is no single definition of risk, there is no single one nor a single definition of risk management. Often management defines risk as a systemic process that involves determining and measuring the risks to which organizations and individuals are exposed, as well as selection and implementation of the most adequate risk management methods. Risk management is the process by which they are identified, assessed and address risks using consistent and repeatable procedures and methods for parts or the entire organization. Risk management does not seek to completely eliminate risks, as this is practically impossible, but to create an environment in which optimal business decisions can be made taking into account the identified risks and the consequences they may cause (Radić, 2014).

Risk assessment during a global pandemic is not an easy task, especially if all aspects of risk, types, levels of manifestation and consequences are taken into account. Experts are expected to formulate clear, unambiguous and non-politicized conclusions, on the basis of which public policies will be formulated. When the situation is complex and with serious consequences for individuals and society, the question is whether epidemiologists are the only ones called upon to formulate public policies in the current situation? Is it necessary to include economists, psychologists, sociologists, statisticians and other experts, who would provide answers within the multidisciplinary team on crisis communication strategies, change management and assessments of health, psychological and economic losses (Čabarkapa, 2016)?

The situation with coronavirus pandemic belongs to the domain of complex conditions, which are characterized by unclear connections between causes and consequences, as well as the possibility to establish only retrospectively whether the management of the crisis and the resulting changes was successful or not. Current public policies seem to be formulated as if the situation is structured, with clear cause-and-effect relationships, so it is possible to apply previously established best practices and apply them in a new context. However, the question is which risk assessment paradigm is applied here - axiomatic, socio-cultural or statistical? In the beginning, the universal axiomatic approach was dominant, but the further development of events with virus spread, frequency of diseases and deaths, soon showed that the socio-cultural context must be respected and appropriate statistical models used to assess complex risk (Živkovic \& Čabarkapa, 2020).

Although there have been major pandemics in the past, none has shaken the whole world and all areas of social life as is the case with the corona virus pandemic. In addition to human health and life, the most severe consequences are manifested in the global economy, because the pandemic affected all social and economic areas. Due to the difficult movement of people, goods and capital, the functioning of economic entities is significantly hindered, so the key business risks have increased. The current pandemic has led to a changing environment and the emergence of a large number of emerging risks. These risks are most pronounced in areas where human resources are key and in areas where the importance of technology is growing due to teleworking. By working remotely, the usual way of life and functioning of people has changed 
a lot. In a word, the world was not ready enough to deal effectively with such a devastating and devastating crisis.

As with all long-lasting dramatic events, which claim many lives every day and produce great material losses, researchers will need a lot of time, effort and commitment to comprehensively and in-depth look at the key aspects of this pandemic, as well as its real causes and long-term consequences. But it can already be stated that the coronary virus pandemic has exposed numerous risks and vulnerabilities of the digitalized, robotic and globalized world. It is, in fact, a kind of reflection of the world in which we live, with all its virtues and flaws.

\section{CONCLUSION}

The coronavirus pandemic has already affected our lives forever. The way we work, shop, eat, seek medical advice, socialize, participate in sport, and entertain ourselves will all be different. Quite how different remains to be seen, but all industries must plan ahead for multiple eventualities.

The decline in car sales in 2020 is $16 \%$ compared to 2019 , which is a bigger one-time shock than during the financial crisis of 2008-2009. As for 2021, a jump of almost $15 \%$ is expected. However, in global markets, pre-pandemic sales are not expected to reach pre-2023 due to the creeping macroeconomic effects of the coronavirus-induced recession. Following the announcement of the vaccines, air traffic is expected to increase by $50-75 \%$ in 2021 . Job losses impact remains uneven, however, with over $80 \%$ come from Europe and the United States. Banks and payment companies are accelerating digital adoption. Consumers are reducing cash consumption, and banks have hired their digital channels for everyday needs.

Economic uncertainty and price awareness continue to affect readiness for consumption, and food and household products remain the only sector to record higher growth this year than before the pandemic. Firms recognize direct-to-consumer activities, as well as continuous investment in corporate social responsibility as necessary to mitigate losses. The volumes of hospital procedures are recovering, but the recovery is hindered by the second and third waves, as well as the appearance of potentially more contagious variants of the virus. Continuation of recovery depends on the successful application of vaccines, which will primarily reduce mortality rates in hospitals and enable a greater focus on the development of necessary therapies. The race for effective treatments and vaccines continues. Currently, there are 3.761 clinical trials for coronavirus and promising clinical data are beginning to emerge for vaccines. The tourism industry did not experience the turnaround it had hoped for. The summer holiday period initially provided great hope, but an increase in the infection rate in Europe led to the reimposition of domestic and international travel restrictions that halted the recovery. It should be noted that the recovery is not the same in geographical terms either. As Europe continues to fight the resurgence of COVID-19 cases, parts of the Asia-Pacific region are showing signs of recovery. This is most noticeable in China, Taiwan and New Zealand. Moreover, restrictions on domestic and inter-state travel were eased in early December, a clear signal of progress.

Based on the reports of eminent international organizations and portals, specialized in monitoring and analysis of natural crises and catastrophes, the number of natural crises and catastrophes around the world is growing, their consequences and impact on people, the environment and everyday life are increasing. If natural disasters are accompanied by technicaltechnological and anthropogenic crises and catastrophes, global climate change, urban overcrowding, lack of drinking water in much of the world, pressure on critical infrastructure 
and services, the risk of new diseases and epidemics, a conclusion is reached that the $21 \mathrm{st}$ century will be a century of increasingly frequent crises, which will have increasingly serious consequences, while the mechanisms of prevention, preparedness, control and response are generally lagging behind. Due to all the above factors of real and potential danger, there is an urgent need to establish new risk assessment and control mechanisms at the national and global levels.

\section{REFERENCES}

Acemoglu, D., Chernozhukov, V., Werning, I., \& Whinston, M. D. (2020). A Multi-Risk SIR Model with Optimally Targeted Lockdown. NBER Working Paper No. 27102, Cambridge, USA.

Alvarez, F., Argente, D., \& Lippi, F. (2020). A Simple Planning Problem for COVID-19 Lockdown. NBER Working Paper 26981, Cambridge, USA.

Bomey, N. (2020). Marriott furloughs tens of thousands of employees due to coronavirus. Available at https://www.usatoday.com/

Borko, S. (2020). Hotels Chains Maneuver to Deal with Coronavirus Gut Punch. Available at https://skift.com/2020/03/18/hotelschains-maneuver-to-deal-with-coronavirus-gutpunch/

Čabarkapa, M. (2016). Stres - opšti modeli, uzroci i posledice. Institut za psihologiju. Belgrade, Serbia: Fakultet za filozofiju.

International Air Transport Association (2020). COVID-19 Puts Over Half of 2020 Passenger Revenues at Risk. Available at https://www.iata.org/en/pressroom/pr/2020-04-14-01.

International Civil Aviation Organization (2020). Effects of Novel Coronavirus (COVID-19) on Civil Aviation: Economic Impact Analysis. Montréal, Canada.

Jones, C. J., Philippon, T., \& Venkateswaran, V. (2020). Optimal Mitigation Policies in a Pandemic: Social Distancing and Working from Home. NBER Working Paper No. 26984, Cambridge, USA.

Organisation Internationale des Constructerurs d' Automobiles (2020). Production statistics. Paris, France.

Radić, V. (2014). Upravljanje rizicima u vojnoj industriji. Belgrade, Serbia: Copy planet.

Radić, N., Radić, V., \& Ravić, N. (2020). Uticaj pandemije korona virusa na ciljeve održivog razvoja i ekonomiju. Ecologica, 27(99), 366-375.

Radić, N., Radić, V., \& Stevanović, M. (2020). Ekonomski uticaj pandemije korona virusa na automobilsku industriju. Oditor, 6(3), 72-88.

Radić, N., Radić, V., \& Stevanović, M. (In Press). Ekonomski efekti pandemije korona virusa na turizam i ugostiteljstvo, Megatrend revija.

Richter, F. (2020). Pandemic Could Set Tourism Sector Back by \$1 Trillion.Available at https://www.statista.com/chart/22689/global-international-tourism-receipts/

STR (2020). Europe hotel performance for March 2020. Available at https://str.com/pressrelease/str-europe-hotel-performance-march-2020.

World Tourism Organization (2020). World Tourism Barometer. Available at https://www.eunwto.org/doi/epdf/10.18111/wtobarometereng.2020.18.1.6.

World Travel \& Tourism Council (2020). Economic Impact Reports \& Trends. Available at https://wttc.org/Research/Economic-Impact

Živković, S., \& Čabarkapa, M. (2020). Psihološka procena rizika u kriznoj situaciji. Kvalitet \& Izvrsnost, No. 11-12, 28-31. 